\title{
Stuck with the Sur-face: An Ethical Approach to Facial Disfigurement in Willa Cather’s “The Profile”
}

\author{
Gudrun M. Grabher \\ University of Innsbruck
}

\begin{abstract}
The human face consists of three dimensions: (1) the visible, static sur-face, (2) the mobile dimension, which communicates thoughts, emotions, and states of mind, and (3) the invisible dimension, the face as pars-pro-toto for the whole person who owns the face. In this latter sense, the human face is at the center of Emmanuel Levinas' theory of ethics: We encounter each other face-to-face, he argues, and it is the other's face that calls for my ethical response to the holiness of his/her wholeness and essence. The primary ethical imperative is: "Thou shalt not kill." When we encounter a facially disfigured person, we usually fail to respond ethically because we concentrate on the disfigurement. The second dimension, as a result of the disfigurement, is often impaired and thus incapable of communicating in such a way that we can "read" the face. With our gaze fixed on the disfigured part of the face, we lose sight of the person as a whole. Metaphorically speaking, we could even say that we "kill” the person. Levinas conceives of the other's face not in its plastic manifestation. But the encounter with the other does at first take place as embodiment. According to Merleau-Ponty, this encounter is by definition interactive and dialogical. In Willa Cather's short story “The Profile,” young beautiful Virginia marries a portrait painter after he has finished her portrait in profile. The left side of her face is severely disfigured because of a burn. Her husband is waiting impatiently for her to talk about "it" and the suffering it must cause her in order to "heal" her with his love, but she behaves as if it did not exist and even likes to dress extravagantly. In the following analysis of the short story, it will be illustrated how the husband fails to respond to his wife's face's invitation to interact with it and get in touch with the wholeness of her person that it stands for. Instead, he reduces her to the disfigurement. When he finally names the scar, he metaphorically "kills" her, as well as their marriage.
\end{abstract}

Keywords: the human face, facial disfigurement, ethics of the face (E. Levinas), phenomenology (Merleau-Ponty), lived embodiment, the visual arts, Victor Hugo

Am I supposed to paint what is on the face, what is in the face, or what is behind the face? Pablo Picasso

In Willa Cather's short story "The Profile," first published in 1907, Aaron Dunlap, an American artist specializing in portrait painting and gifted in "transferring personalities to his canvas" (Cather 1965, 125), falls in love with and marries Virginia, a beautiful young woman, except that the left half of her face is severely disfigured: "It (the disfigurement) had evidently been caused by a deep burn, as if from a splash of molten

Gudrun M. Grabher, full professor, Ph.D., Department of American Studies, University of Innsbruck, Austria; main research fields: American Poetry, Literature and the Arts, Literature and Philosophy, Medical Humanities, and Legal Narratives.

This manuscript is part of a book-length study in progress on "American narratives about facial disfigurement based on Levinas' ethics of the face.” 
metal. It drew the left eye and the corner of the mouth; made of her smile a grinning contortion..." (Cather 1965, 128). Dunlap is commissioned by Virginia's father to paint her portrait. When asked how she wishes to sit for him, she suggests a profile. Cather, as pointed out by several critics, had a special liking for artists: "Her concern with... artists as symbolic figures representing the unending human quest for beauty and truth" has been recognized as part of the writer's moral agenda (McFarland 1972, 5). The story is told from an omniscient narrator's point of view, and before it deals with the artist's obsession with his wife's facial disfigurement, the artist himself is introduced as an "almost morbidly sensitive" (Cather 1965, 126) man. As a child, he suffered under the violence and cruelty of his alcohol-addicted grandfather and as a result he seems to possess "the sadness of knowledge” (Cather 1965, 126), which shows in his portrayals of beautiful female faces. As Frances Zauhar observes, Cather's “artists usually attain accomplishment and insight only after enduring suffering and loss” (Zauhar 2007, 248). While Virginia does not seem to be bothered by her disfigurement at all, Dunlap becomes more and more obsessed with it and especially with the necessity to talk about it. When one day Virginia, fascinated with physical beauty and fancy garments, dresses up and underlines her disfigurement with a pink bow right underneath it, Dunlap is outraged and rudely tells her not to emphasize her scar. This scene marks the end of their marriage, though not the end of the story. It is this part of the story on which the following analysis will concentrate.

Plastic surgeons and psychologists, for example Frances Cooke Macgregor, have investigated the impact of facial disfigurement on people affected in regard to their self-perception and self-esteem, or rather, the lack thereof. The focus of the following analysis, however, is on the reaction to facial disfigurement and on the question of how one ought to react. It thus opens up an ethical horizon, which is here based on Emmanuel Levinas' theory of the face. We encounter each other face-to-face, Levinas argues, and in this encounter the other's face appeals to me, and it demands of me to ethically respond to him/her. However, Levinas is not concerned with the plastic manifestation of the face. Rather, the face of the other reveals the other in his/her wholeness and essence, which is invisible.

To manifest oneself as a face is to impose oneself above and beyond the manifested and purely phenomenal form, to present oneself in a mode irreducible to manifestation, the very straightforwardness of the face to face, without the intermediary of any image, in one's nudity, that is, in one's destitution and hunger. (Levinas 1969, 200)

Levinas speaks of the holiness of his/her wholeness. He distances himself from the traditional Western approaches to the other, both the transcendental and the dialogical one, the former constituting the other like any other object in the world, the latter taking the symmetrical relation of I and Thou for granted. Levinas reverses the intentionality of the transcendental approach and unravels the symmetry of the dialogical one. The other is, according to Levinas, not part of my horizon of totality but belongs to what he calls the horizon of transcendence and infinity. The priority is with the other rather than with the (Cartesian) I. As such, the other's face is regarded by Levinas as a trace of the ultimate infinity, which to him is god or the divine. "The face speaks. The manifestation of the face is already discourse. He who manifests himself comes, according to Plato's expression, to his own assistance. He at each instant undoes the form he presents" (Levinas 1969, 65-66). Thus, the face is both "form” and "event” for Levinas, as Jeffrey D. Bloechl has poignantly remarked. Bloechl continues: "In the event of being faced, the corporeal face is what confronts me, what I recognize, what makes the experience intelligible. And what I recognize there is the self-expression of an otherness already beyond my reach in a sense that things or words are not. The face, as expression, is excessive (and...) 
withdraws from contact and appropriation” $(1996,4)$. If, however, the face of the other is appropriated, its owner is thus annihilated.

The human face is of huge significance. Not only is it our foremost marker of identity, it is also our major tool for communication. It harbors four of our senses, and it displays, as much as it hides, what is going on inside our brains. "Humans are able to recognize and derive a tremendous amount of knowledge from a human face” (Sudweeks and Simoff 1999, 4). We gain knowledge from the face in its structural dimension about the unique identity of the person as well as categorical information about their sex, age, race, and other characteristics. The face, moreover, as "a window to the inner feelings and moods of the individual through the rich facial musculature" (Sudweeks and Simoff 1999, 4), reveals its functional and communicative dimension. As is well known, Paul Ekman and others have offered numerous studies of the face and guidelines as to how to read and interpret what we see in a facial expression, even across cultures. Most importantly, the face is exposed and visible to the others. In addition to signifying our identity and serving as a major tool for communicating with others, in its ambivalent power to both reveal and conceal what is going on inside our brain, there is ultimately a dimension of the face that is "invisible.” The face conjures up the totality of the other, his/her very essence beyond that which can be seen and communicated through facial expression and features in motion. But this invisible dimension is also the mystical side to this enigma that is called face. The phrase "we encounter each other face-to-face" thus contains all of these three dimensions of the face: the visible (we see each other's face), the dynamic (we interact with each other by reading faces and responding to them), and the invisible (we make contact with each other's essence, get in touch with his/her mystical totality). When we encounter the other face-to-face, his/her face is, according to Levinas, "both this fleshy surface with eyes and nose and mouth, and the act in which it turns toward me" (Bloechl 1996, 4). It is crucial to understand that "the corporeal face confronts me" (Bloechl 1996, 4) and thus enters my experience, but the face as expression is "excessive" and "overflowing" and "allows the other person, as other, to withdraw from anything I could make of him or her" (Bloechl 1996, 4). The other's retreat from my appropriation coincides with the arrival of its appeal.

When someone's face is disfigured, this encounter face-to-face is disrupted: The visible dimension of the face is distorted, and rather than seeing the face as a whole, we see the disfigured part. What is visible is no longer the face as a whole but its disfigurement. In a severely disfigured face, its dynamic capabilities may be affected and impaired as well. The facial features and gestures are no longer decipherable for us, and as a result we shut down the communicative approach to that other's face. With the visible and the dynamic dimensions gone, we completely lose sight of the person who owns this face, and are deprived, or deprive ourselves, of the access to its invisibility: We do not get in touch with the mystical wholeness and essence of the owner of such a face. The disfigured face is flat-ironed into one dimension, with the disfigurement being the sole focus. Its second and third dimensions are cancelled out. What happens in our encounter with a disfigured face is therefore the exact opposite of what Levinas' ethics of the face requires: Our attention is drawn to the disfigurement, and precisely because of the disfigurement, this face not only becomes visible in its plastic self-manifestation, but the visibility of the face is reduced to the disfigurement and we lose sight of the person who owns that face, of their holiness in their wholeness. In his book Perspectives on the Face, Michael Cohen points out that "it is sometimes suggested that communication by facial expression is necessary to define a face" (2006, 4). If facial expression is impaired or even impossible because of a disfigurement, can we still speak of a face? 
Several of Willa Cather's critics have observed that the author had a strong aversion to and even fear of physical defects and mutilation in human beings, ${ }^{1}$ which is reflected in a number of her writings. In her short story "The Profile," however, she seems to have changed her approach to this topic, as Sheryl Meyering argues: "Her tendency had been to present the grotesque as external to human lives, something to be exorcised and suffered. In this story, however, she fuses the beautiful and the ugly, the joyful, and the painful, suggesting that love can reconcile the opposites" $(1994,208)$. While it is true that in the short story at hand the deformity is no longer externalized but visibly present on the face of a beautiful young woman, it is exactly the power of love, however, that goes astray, as will be demonstrated in the following analysis.

“... Willa Cather... could and did write almost any kind of story,” concedes Donald Sutherland and recognizes her "real strength" in a "special kind of concentrated realism, in reduction rather than complication or augmentation" $(1974,177)$. "The Profile" focuses on the interior world of her characters' psyche and is about the human voice, as one may argue with Richard Giannone: "The essential drama of living for Willa Cather takes place behind the brow... Such people whose inner being is their destiny are the heroes and heroines of Cather's fictions" $(1974,21)$. In this story, it is the human face that is given a voice of its own. It is strongly reminiscent of Hawthorne's “The Birth-mark,” in spite of the husband's much less disgusted reaction to his wife's facial disfigurement. However, as James Woodress points out, neither of the men can resist the obsession that gets hold of them. "The Profile" is

a story laid in Paris about a painter who marries a woman badly disfigured by a scar on her face. Its denouement is a tragedy growing out of the painter's obsession with his wife's scar. The psychological drama enacted reminds one of James in its narrative technique and Hawthorne in its theme and subject, particularly such a story as "The Birthmark." (1970, $124 \mathrm{f})^{2}$

And yet, the husband's obsession with his wife's disfigurement manifests itself quite differently in Hawthorne's and in Cather's short story. While Aylmer needs to get rid of it, Cather's protagonist can live with it. Or so it seems.

In the short story at hand, Dunlap unconsciously excludes the possibility that his wife may not suffer under her scar. On the contrary, his whole attitude and behavior towards her is based on the unquestioned assumption that being severely disfigured as she is, she must suffer. However, as Erving Goffman in his book about stigma points out, Virginia's attitude of ignoring her facial disfigurement is not an unheard-of strategy among people like her: "The cooperation of a stigmatized person with normals in acting as if his known differentness were irrelevant and not attended to is one main possibility in the life of such a person” (1990, 57). Nevertheless, Virginia is a character not easy to grasp or understand; but neither is her husband, this being a trademark of Willa Cather's literary writings. "W. C. Brownwell said: 'I don't know of any art more elusive (than Cather's)'” (Slote and Faulkner 1974, vii). It seems that Cather intentionally misleads her reader by presenting Dunlap as an oversensitive man who seems to empathize with his wife, imagining how painful it must be for her to live with her scar, and how talking with him about it, sharing this unbearable burden with him, would alleviate her suffering, and he could thus heal her with his love. From this perspective, Virginia strikes us as superficial and hollow, indulging in extravagant garments, being obsessed with appearance, while he is interested in what hurts the soul. At the same time, Cather offers hints and references that open up a different hermeneutic horizon.

A critical look at the interaction between Virginia and Dunlap sheds a different light on their encounter face-to-face. According to Merleau-Ponty, for whom the invisible is manifest in and through the visible, the 
human body is highly significant; he not only "establishes the body as the axis of human existence and cognition" (Gill 1991, 2), but also emphasizes the interactive character of our existence and cognition. It is possible for us to bridge the gap between the other and me "by virtue of our embodied involvement with the world” (Gill 1991, 7). Through perception, we have knowledge of existences. The eye plays a crucial role for the embodied involvement with the world and the dialogical, interactive quality of this involvement: "My eye for me is a certain power of making contact with things, and not a screen on which they are projected. The relation of my eye to the object is not given to me in the form of a geometrical projection of the object in the eye, but as it were a hold taken by my eye upon the object” (Merleau-Ponty 1962, 279). Moreover, Merleau-Ponty speaks of the visual and spatial perspective when we see the things in the world in this sense: “Is not to see always to see from somewhere?” (Gill 1991, 11). Vision, as he says, is "an act of two facets” (Gill 1991, 11). The description of the encounter between Virginia and Dunlap when it is decided that he will paint her in profile, is revealing: When first introduced to Virginia, he is, above all, puzzled by Virginia's "unconsciousness, her utter openness and unabashedness" (Cather 1965, 127). He is convinced that the accident which caused her deformity must have happened very recently and that she has not yet caught sight of her appearance in a mirror, as otherwise she would be "suffocated with shame" (Cather 1965, 127). She asks him how he would like her to sit for him, but he leaves the decision to her. Virginia, carelessly, suggests: "Suppose we try a profile, then?” (Cather 1965, 128). But having the "clear profile” (Cather 1965, 128) in front of him, Dunlap feels an irresistible desire to look at the hidden side of her face: "He went behind her chair to experiment with the window shades, and there, as he drew them up and down, he could look unseen. He gazed long and hard, to blunt his curiosity once and for all and prevent a further temptation to covert glances" (Cather 1965, 128; emphasis added). The face, by being stared at, comments Wenzel on Levinas, loses its face (Wenzel 1994, 196). By “gaz(ing) long and hard,” Dunlap violates Virginia’s face.

On all three levels described before, Dunlap's interaction with Virginia fails. Her response, formulated as a question, "Suppose we try a profile, then?" opens the door to the embodied interaction: through the interrogative mode, by using the personal pronoun "we," which includes both him and her, and by suggesting a profile. A profile is the shape of a face as seen from the side. But we know from gestalt psychology that when seeing one half of the face, as in a painted profile, we silently add the other half, which is invisible. The visible half of the face is complemented by our imaginative eye: We automatically assume that the other half resembles and mirrors the one we see. Suggesting a profile, Virginia wants him to see beyond the visible and obvious, offering him the possibility to see her in her wholeness. This dimension of wholeness is also contained in the word "profiling," which means to outline a person's characteristics. The encounter with the other's face happens through seeing, but not only through seeing; the face of the other speaks, says Levinas. In the encounter of the other's face, seeing, hearing, and speaking are therefore involved (Römpp 1989, 131). Interaction is done and lived, says Merleau-Ponty. Virginia's question is an invitation: "Let's do my profile together." It may not succeed—she emphasizes "we try" — but the possibility is there. However, Dunlap rejects her invitation. He reads her wish to have her portrait painted in profile as her desire and need to hide the other side, the disfigured one. Rather than encountering her face-to-face, which would offer him the opportunity to see not only what is on, but also what is in and behind her face, he prefers to "look unseen," as it literally says in the narrative. Virginia expresses Merleau-Ponty's conviction that the other has this immense power to see us; Dunlap, however, escapes this mutuality. His stepping behind the chair signals his change of spatial perspective. And what he wants to see, himself unseen, is the thing on her face. The thing on her face, the scar, the 
disfigurement, as it settles in his eyes, replaces not only her face but Virginia as a whole. On a metaphorical level, he sentences her to death. He pronounces the verdict when he blurts out much later in the crucial scene, “'For heaven's sake, Virginia, take that thing off'... 'You ought really to be more careful about such extremes. They only emphasize the scar"” (Cather 1965, 133-4). This is the only time that "the scar" is verbally articulated between them. Seeing only the scar, Dunlap objectifies his wife and thus annihilates her.

Cather underlines this reading by means of another strategy. Before the plot of the story begins, a three-paragraph preliminary discussion among artists at the "Impressionists' Club" prepares for the theme of disfigurement in art in general, and in the short story at hand in particular. The assembled painters agree that disfigurement and dismemberment "have no proper place in art" (Cather 1965, 125). Anything "diverging from the human type" (Cather 1965, 125) deserves to be dismissed. Of particular interest are the (mythological and fictional) examples of dismembered and disfigured creatures that are mentioned, especially Circe, the Greek goddess and sorceress who turned Odysseus' companions into swine, as well as three characters from novels by Victor Hugo: Quasimodo, the hunchback of Notre Dame, Triboulet, a jester dressed all in red, and Gwynplaine, “the man who laughs" (which is the title of Hugo's novel L'Homme qui rit, published in 1869). A physically deformed human being, the artists argue, must be banned from the canvas since, as one old painter remarks, if you "lop away so much as a finger... you have wounded the creature beyond reparation" (Cather 1965, 125). The horrors that are admitted to the realm of the artist are, according to him, the "psychological" ones only (Cather 1965, 15). In the midst of this conversation, Dunlap leaves the room and his fellow artists, who "felt that this was a subject which might well be distasteful to him (Dunlap)" (Cather 1965, 125).

By only dropping those names, Cather invites her reader to uncover their identity as well as their stories. It is the story of Gwynplaine and Dea (The Man Who Laughs) that sheds light on the one to follow about Dunlap and Virginia. The two characters in Hugo's novel manifest the utmost of human misery. "Each seemed born in a compartment of the sepulcher; Gwynplaine in the horrible, Dea in the darkness" (Hugo 2013, 154). Gwynplaine's face is compared to a clown's mask because it is severely disfigured and distorted into a perpetual grin, "a little more and a little less than a beast” (Hugo 2013, 155). Dea is a beautiful and virtuous girl, who is blind. She is described as a radiant, "celestial” creature (Hugo 2013, 153). They fall in love with each other, and their love is perfect as they are the perfect matches. When Dea tries to "see" Gwynplaine by moving her fingers across his face, she concludes that he must always be happy because he is permanently smiling. Therefore, Chapter III of Book 2 begins with the epitaph in Latin, “Oculos Non Habet, Et Videt” (She has no eyes, and sees) (Hugo 2013, 154). And the first sentence of this chapter reads: "Only one woman on earth saw Gwynplaine. It was the blind girl” (Hugo 2013, 154). Unable to see in the physical sense of the term, Dea can "see" the man as a whole, his essence and personality: "Where the multitude saw the monster, Dea recognized the archangel. It was that Dea, blind, perceived his soul” (Hugo 2013, 155-6). By passing her fingers over his face, she can "see" what is on, in, and behind it. But Dunlap misjudges his own situation: "Was she not living for the moment when she could throw down the mask and point to it and weep, to be comforted for all time? He looked forward to the hour when there would be no lie of unconsciousness between them” (Cather 1965, 129), as it says in the story. As Virginia never addresses it, the disfigurement, he feels that their life is "enmeshed in falsehood" (Cather 1965, 130). He becomes irritable, and has a hard time controlling himself because of "the repression he put upon himself” (Cather 1965, 130). "Whereas he had once seen the scar on his wife's face not at all, he now saw it continually. Inch by inch, it had crept over her whole countenance. Yet the scar itself seemed now a trivial thing; he had known for a long time that the burn had gone deeper than the flesh" 
(Cather 1965, 130). As pointed out before, the scar expands inch by inch and replaces Virginia's face as well as herself.

The scar having been named, it lingers between Virginia and Dunlap, separating forever the I from the other, the seer from what he could have seen but refused to see. No wonder that Dunlap is incapable of understanding what is in her face when it speaks to him without using words. The following scene describes Virginia's reaction after he has spelled out the word "scar" to her:

... She caught her breath and wheeled suddenly about, her face crimson and then gray. She opened her lips twice, but no sound escaped them. He saw the muscles of her throat stiffen, and she began to shudder convulsively, like one who has been plunged into icy water. He started toward her, sick with pity; at last, perhaps-but she pointed him steadily to the door, her eyes as hard as shell, and bright and small, like the sleepless eyes of a reptile. (Cather 1965, 133-4)

"He started toward her, sick with pity; at last, perhaps"-dash, but. He believes that this is the moment when Virginia will finally speak to him about it, creating a connecting bridge between the two. He does not realize that he just blew that bridge off forever. The seer who sees what is on the face, but neither what is in it nor what is behind it, is blind. "Oculos non habet, et videt," describes the seeing of Dea, "oculos habet, et non videt" (he does have eyes, and does not see) might describe the blindness of Dunlap. According to Merleau-Ponty, the visible both veils and unveils the invisible (Gill 1991, 74). As Jerry H. Gill in his book about Merleau-Ponty and metaphor has pointed out, “... in Merleau-Ponty’s mind, a proper understanding of intangible reality is not a matter of getting beyond, or behind, or beneath tangible reality. Rather, it is a matter of, as the title of Owen Barfield's book would have it, 'saving the appearances;' they alone mediate the intangible” (Gill 1991, 75f).

Instead of "sav(ing) the appearances," Dunlap destroys them and thereby erases the visible door to the invisible. He is incapable of preserving and respecting the other as other, mistaking his wife for an alter ego instead of recognizing her as what he is not. Projecting his own feelings and experiences onto her, he appropriates and integrates her in his sphere of the same. "To preserve the other as other, it must not become an object of knowledge or experience, because knowledge is always my knowledge, experience always my experience; the object is encountered only in so far as it exists for me, and immediately its alterity is diminished" (Davis 1996, 41). His craving for speaking with her about her scar is a misconception of affinity and community as "the face to face does not establish a coy intimacy between myself and the Other; it shows me the existence of a whole world outside myself" (Davis 1996, 52). His response to Virginia's facial disfigurement is as to a spectacle that draws his gaze, which annihilates her. Objectifying her face, he is unaware of its appeal. Its command remains unheard, as he is stuck with the sur-face.

\section{Notes}

1. A personal experience in Cather's life had obviously triggered in her a special fear of dismemberment, as James Woodress has pointed out: "The rather trivial accident ('she tore the big tendon of her left wrist... and for three months had to have her hand strapped to a thin board day and night') to her hand was for Willa Cather a traumatic experience. Since her childhood when a half-witted boy had threatened to cut off her hand, she had had a terror of mutilation" (1970, 248-9).

2. Woodress has also pointed out the fact that Cather modeled the story on the basis of a friend's disfigurement: “... McClure's staff tried to talk her out of publishing the tale on grounds that it would hurt the friend on whose physical disfigurement it was based. The story appeared in the magazine, however, and nothing happened...” (1987, 191). Sheryl Meyering explains the background in more detail: "While they (Cather and her friend Isabelle McClung) were in Paris (1902), Cather was introduced to one of Canfield's friends, a fellow graduate student named Evelyn Osborne, who dressed lavishly and had a 
conspicuous scar on her face. Two years later, in December 1904, Canfield read 'The Profile' for the first time and was convinced that the central character was a thinly disguised version of her friend Evelyn. Canfield then wrote to Cather, begging her not to publish the story; she was convinced it would destroy Evelyn's already limited self-esteem (and) that seeing the story in print might push Osborne to suicide" $(1994,206)$.

\section{Works Cited}

Bloechl, Jeffrey D. “How Best to Keep a Secret? On Love and Respect in Levinas' 'Phenomenology of Eros.” Man and World: An International Philosophical Review 29 (1996): 1-17.

Cather, Willa. “The Profile.” Willa Cather's Collected Short Fiction 1892-1912. Vol. I: The Bohemian Girl. Lincoln: U of Nebraska Press, 1965. 125-35. (First published in McClure's XXIX. June 1907. 135-40.)

Cohen, M. Michael Jr. Perspectives on the Face. Oxford: Oxford UP, 2006.

Davis, Colin. Levinas: An Introduction. Cambridge: Polity Press, 1996.

Giannone, Richard. "Willa Cather and the Human Voice.” Ed. John Murphy. Five Essays on Willa Cather. The Merrimack Symposium. North Andover: Merrimack College, 1974. 21-49.

Gill, Jerry H. Merleau-Ponty and Metaphor. Atlantic Highlands, NJ, and London: Humanities Press, 1991.

Gilman, Sander L. Creating Beauty to Cure the Soul: Race and Psychology in the Shaping of Aesthetic Surgery. Durham and London: Duke UP, 1998.

Goffman, Erving. Stigma: Notes on the Management of Spoiled Identity. London: Penguin Books, 1990 (1963).

Hugo, Victor. The Man Who Laughs. EBook. Moorside Press, 2013.

Landau, Terry. About Faces: The Evolution of the Human Face. New York: Anchor Books, 1989.

Lévinas, Emmanuel. Totality and Infinity: An Essay on Exteriority. Trans. Alphonso Lingis. Pittsburgh: Duquesne UP, 1969 (1961).

Macgregor, Frances Cooke. Transformation and Identity: The Face and Plastic Surgery. New York: Quadrangle/The New York Times Books Company, 1974.

McFarland, Dorothy Tuck. Willa Cather. New York: Frederick Ungar Publishing Co., 1972.

Merleau-Ponty, Maurice. Phenomenology of Perception. Trans. C. Smith. London and New York: Routledge and Kegan Simone Ltd., 1962.

---. The Visible and the Invisible. Trans. Alphonso Lingis. Evanston: Northwestern UP, 1968.

Meyering, Sheryl L. A Reader's Guide to the Short Stories of Willa Cather. New York: G.K. Hall \& Co., 1994.

Römpp, Georg. "Der Andere als Zukunft und Gegenwart: Zur Interpretation der Erfahrung fremder Personalität in temporalen Begriffen bei Lévinas und Husserl.” Husserl Studies 6 (1989): 129-54.

Slote, Bernice and Virginia Faulkner. “Introduction.” Eds. Bernice Slote and Virginia Faulkner. The Art of Willa Cather. Lincoln: U of Nebraska Press, 1974. vii-xii.

Sudweeks, Fay and Simeon J. Simoff. "Quantifying Beauty: An Information System for Evaluating Universal Aesthetics.” Proceedings of the Second Western Australian Workshop on Information Systems Research. Perth, Australia, 1999. 1-6. Online source. 9 Jan. 2016.

Sutherland, Donald. "Willa Cather: The Classic Voice.” Eds. Bernice Slote and Virginia Faulkner. The Art of Willa Cather. Lincoln: U of Nebraska Press, 1974. 156-82.

Wenzel, Uwe Justus. “'Beziehung ohne Beziehung’: Bemerkungen zur Gesellschafts- und Gemeinschaftskritik von Emmanuel Lévinas.” Studia Philosophica 53 (1994): 177-99.

Woodress, James. Willa Cather: Her Life and Her Art. Lincoln and London: U of Nebraska Press, 1970.

---. Willa Cather: A Literary Life. Lincoln and London: U of Nebraska Press, 1987.

Zauhar, Frances. "Violent Art, Sacred Art: Artists and Sacrifice in Willa Cather.” Eds. Joseph R. Urgo and Merrill Maguire Skaggs. Violence, the Arts and Willa Cather. Madison, Teaneck: Farleigh Dickinson UP, 2007. 248-60. 